\title{
Effects of Drought Stress on Leaf Gas Exchange Parameters in Development of Sweet Cherry Fruit
}

\author{
Jin Wang ${ }^{1, a}$, Ju Guan ${ }^{2, b}$ and Xiulan Lv $v^{1, c *}$ \\ ${ }^{1}$ Institute of Pomology and Olericulture, Sichuan Agricultural University, Chengdu, Sichuan, China \\ ${ }^{2}$ College of Horticulture, Sichuan Agricultural University, Chengdu, Sichuan, China \\ a251040278@qq.com, b1250431854@qq.com, '1933063229@qq.com \\ *Corresponding author. Jin Wang and Ju Guan contributed equally to this work.
}

\begin{abstract}
Keywords: Drought stress; Prunus avium; Leaf gas exchange; Fruit development period
Abstract: Aim at the drought, one of the important stress factors, we chose the Prunus avium named 'Hong Deng' to experiment. Through artificial control field soil water content, to different drought stress treatment of sweet cherry, the leaf photosynthetic indicators, including net photosynthesis rate, transpiration rate, stomatal conductance, intercellular $\mathrm{CO}_{2}$ concentration and. instantaneous water use efficiency were measured in the first fruit enlargement period, the stone hardening period, and the second fruit enlargement period of sweet cherry, which provided some knowledge of the $P$. avium under drought stress.
\end{abstract}

\section{Introduction}

Prunus avium which is the sweet cherries is native to the coasts of the Caspian Sea and Western Asia, and it has developed into an important economic fruit in the Western Sichuan province north of the Minjiang River Valley [1]. It has a large content of ferrum, calcium and other mineral, and the content of vitamin $\mathrm{C}$ in $100 \mathrm{~g}$ pulp was $7-13 \mathrm{mg}$ [2]. Because of the high economic benefits, the growers are very fond of it .Drought is an important adversity factor that affects the normal development of plants [3-4]. The plant photosynthesis and water metabolism and its physiological and ecological mechanisms are the important theoretical basis of water-saving agriculture [5]. How to control soil moisture to form the best combination of plant yield and water use efficiency under the condition of minimizing water consumption is the key and hot issue of water-saving irrigation research [6]. The purpose of this experiment is to provide some knowledge of the $P$. avium under drought stress.

\section{Materials and Methods}

Materials. The experiment was conducted in Mao County Orchard in Aba Tibetan and Qiang Autonomous Prefecture in Sichuan Province, Test materials selected 'Hong Deng' P. avium was planted in 2009, Consistent growth and development.

Experimental Design. Before sweet cheery sprout, the test field moisture content has been determined by water-refilling and water-controlling. Every 7 days sample soil's relative moisture content is tested in order to make that of test plants aborting water field to reach 4 gradients: mild drought (LD), moderate drought (MD), severe drought (SD) and contrasting CK (soil relative water content for $55 \%$ to $60 \%$ of field capacity, $40 \%$ to $45 \%$ of field capacity, $30 \%$ to $35 \%$ of water holding capacity of farmland and $75 \%$ to $80 \%$ of field capacity) [7-8]. This is to enable sweet cherry to have different drought threatening reactions. Put transparent plastic ground film under test plants to cover test field trees. To avoid soil moisture horizontally moving, dig a 60 -cm-deep anti-lateral-seepage ditch $1 \mathrm{~cm}$ under the drip line and bury anti-lateral-seepage plastic thin film. Conduct this to each single plant and repeat three times. Sweet cherry was determine by in the first stage of fruit enlargement period, second times, hard fruit enlargement period selection of fine weather, in the determination of the morning 9:00-11:30, the determination of functional leaves in the upper canopy at the same 3 tablets, treatment with cross determination. 
Statistical Analyses. Statistical analysis was carried out by using SPSS 20.0 statistical software. The data were analyzed by one-way ANOVA, with the least significant difference at the 5\% confidence level.

\section{Results and Discussion}

The leaf photosynthetic indicators, including net photosynthesis rate, transpiration rate, stomatal conductance, Intercellular $\mathrm{CO}_{2}$ concentration and instantaneous water use efficiency were measured in the first fruit enlargement period, the stone hardening period, and the second fruit enlargement period of sweet cherry. The data is shown in the table 1, Table 2 and Table 3.

The net photosynthesis rate, transpiration rate and stomatal conductance of all the treatment groups decreased with the increase of drought stress. During the first fruit enlargement period, the intercellular $\mathrm{CO}_{2}$ concentration of all the treatment groups decreased firstly and then increased with the increase of drought stress. During the stone hardening period, intercellular $\mathrm{CO}_{2}$ concentration of all the treatment groups decreased with the increase of drought stress. The intercellular $\mathrm{CO}_{2}$ concentration of the LD treatment group and SD treatment group increased separately by $9.7 \%$ and $6.0 \%$ compared with the control group under CK treatment in the second fruit enlargement period, while the intercellular $\mathrm{CO}_{2}$ concentration of the $\mathrm{MD}$ treatment group decreased by $17.0 \%$ compared with the control group. In the first fruit enlargement period and the stone hardening period, instantaneous water use efficiency.

Table 1 The gas exchange parameters of the leaves during the first fruit-expansion

\begin{tabular}{|c|c|c|c|c|c|}
\hline Treatments & $\begin{array}{c}\text { photosynthesis } \\
\text { rate } \\
(\mu \mathrm{mol} \\
\left.\mathrm{CO}_{2} \cdot \mathrm{m}^{-2} \cdot \mathrm{s}^{-1}\right)\end{array}$ & $\begin{array}{c}\text { Stomatal } \\
\text { conductance } \\
\left(\mathrm{mol} \mathrm{H}_{2} \mathrm{O} \cdot \mathrm{m}^{-2} \cdot \mathrm{s}^{-1}\right)\end{array}$ & $\begin{array}{c}\text { Intercellular } \mathrm{CO}_{2} \\
\text { concentration } \\
\left(\mu \mathrm{mol} \mathrm{CO}_{2} \cdot \mathrm{mol}^{-1}\right)\end{array}$ & $\begin{array}{c}\text { Transpiration rate } \\
(\mathrm{mmol} \\
\left.\mathrm{H} 2 \mathrm{O} \cdot \mathrm{m}^{-2} \cdot \mathrm{s}^{-1}\right)\end{array}$ & $\begin{array}{c}\text { Instantaneous } \\
\text { water use } \\
\text { efficiency } \\
\left(\mathrm{mmol} \cdot \mathrm{mol}^{-1}\right)\end{array}$ \\
\hline $\mathrm{CK}$ & $13.68 \pm 0.01 \mathrm{aA}$ & $0.103 \pm 0.002 \mathrm{aA}$ & $183.95 \pm 0.016 \mathrm{aA}$ & $0.946 \pm 0.006 \mathrm{aA}$ & $14.45 \pm 0.10 \mathrm{aA}$ \\
\hline $\mathrm{LD}$ & $12.41 \pm 0.05 \mathrm{bB}$ & $0.101 \pm 0.002 \mathrm{aA}$ & $183.69 \pm 0.004 \mathrm{aA}$ & $0.898 \pm 0.003 \mathrm{bB}$ & $13.82 \pm 0.11 \mathrm{bA}$ \\
\hline $\mathrm{SD}$ & $11.95 \pm 0.06 \mathrm{cC}$ & $0.089 \pm 0.001 \mathrm{bB}$ & $125.33 \pm 0.015 \mathrm{cC}$ & $0.846 \pm 0.031 \mathrm{cC}$ & $14.13 \pm 0.48 \mathrm{abA}$ \\
\hline & $10.84 \pm 0.10 \mathrm{dD}$ & $0.086 \pm 0.000 \mathrm{cB}$ & $175.50 \pm 0.74 \mathrm{bB}$ & $0.748 \pm 0.002 \mathrm{dD}$ & $14.49 \pm 0.17 \mathrm{aA}$ \\
\hline
\end{tabular}

Different lowercase letters indicate significant differences based on one-way analysis of variance in SPSS 20.0 followed by the least significant difference test $(p<0.05)$. $\mathrm{CK}=$ control, $\mathrm{LD}=$ mild drought, $\mathrm{MD}=$ moderate drought, $\mathrm{SD}=$ severe drought).

\section{Conclusions}

To explore the long-term drought stress on sweet cherries the first speed, hardcore and embryo development, commodity mature leaf gas exchange parameters, mild, moderate and severe drought stress were inhibited the sweet cherry photosynthetic rate the net photosynthesis rate and transpiration rate, with the degree of drought stress, the bigger the net photosynthesis rate, transpiration rate value reduction. The stomatal conductance value fell under drought stress, and the photosynthetic rate reduced by the influence of stomatal limitation. The stomatal conductance value increased, the photosynthetic rate reduced mainly by the influence of the stomatal limitation. Drought stress at different times, lower photosynthetic rate factor was different, sometimes by the influence of stomatal limitation, sometimes by the influence of the stomatal limitation. Each period of sweet cherry bladed instantaneous water use efficiency depended on the leaf of the net photosynthesis rate and transpiration rate, sweet cherry instantaneous water use efficiency value was the result of the interaction between photosynthetic rate and transpiration rate. 
Table 2 The gas exchange parameters of the leaves during hard stone stage.

\begin{tabular}{|c|c|c|c|c|c|}
\hline Treatments & $\begin{array}{c}\text { Net } \\
\text { photosynthesis } \\
\text { rate } \\
(\mu \mathrm{mol} \\
\left.\mathrm{CO}_{2} \cdot \mathrm{m}^{-2} \cdot \mathrm{s}^{-1}\right)\end{array}$ & $\begin{array}{c}\text { Stomatal } \\
\text { conductance } \\
\left(\mathrm{mol} \mathrm{H} \mathrm{O}_{2} \cdot \mathrm{m}^{-2} \cdot \mathrm{s}^{-1}\right)\end{array}$ & $\begin{array}{c}\text { Intercellular } \mathrm{CO}_{2} \\
\text { concentration } \\
(\mu \mathrm{mol} \\
\left.\mathrm{CO}_{2} \cdot \mathrm{mol}^{-1}\right)\end{array}$ & $\begin{array}{c}\text { Transpiration rate } \\
(\mathrm{mmol} \\
\left.\mathrm{H} 2 \mathrm{O}^{-2} \mathrm{~m}^{-2} \cdot \mathrm{s}^{-1}\right)\end{array}$ & $\begin{array}{c}\text { Instantaneous } \\
\text { water use } \\
\text { efficiency } \\
\left(\mathrm{mmol}^{-1} \mathrm{~mol}^{-1}\right)\end{array}$ \\
\hline $\mathrm{CK}$ & $17.21 \pm 0.01 \mathrm{aA}$ & $0.168 \pm 0.001 \mathrm{aA}$ & $206.63 \pm 1.50 \mathrm{aA}$ & $3.40 \pm 0.11 \mathrm{aA}$ & $5.05 \pm 0.17 \mathrm{cC}$ \\
\hline $\mathrm{LD}$ & $13.64 \pm 0.00 \mathrm{bB}$ & $0.138 \pm 0.000 \mathrm{bB}$ & $196.20 \pm 0.79 \mathrm{bB}$ & $3.04 \pm 0.01 \mathrm{bB}$ & $4.48 \pm 0.01 \mathrm{dD}$ \\
\hline $\mathrm{MD}$ & $9.93 \pm 0.01 \mathrm{cC}$ & $0.078 \pm 0.001 \mathrm{cC}$ & $166.91 \pm 0.02 \mathrm{cC}$ & $1.79 \pm 0.01 \mathrm{cC}$ & $5.52 \pm 0.02 \mathrm{bB}$ \\
\hline $\mathrm{SD}$ & $6.90 \pm 0.02 \mathrm{dD}$ & $0.044 \pm 0.000 \mathrm{dD}$ & $131.95 \pm 0.06 \mathrm{dD}$ & $1.09 \pm 0.00 \mathrm{dD}$ & $6.30 \pm 0.01 \mathrm{aA}$ \\
\hline
\end{tabular}

Different lowercase letters indicate significant differences based on one-way analysis of variance in SPSS 20.0 followed by the least significant difference test $(p<0.05)$. $\mathrm{CK}=$ control, $\mathrm{LD}=$ mild drought, $\mathrm{MD}=$ moderate drought, $\mathrm{SD}=$ severe drought).

Table 3 The gas exchange parameters of the leaves during the second fruit-expansion

\begin{tabular}{|c|c|c|c|c|c|}
\hline Treatments & $\begin{array}{c}\text { photosynthesis } \\
\text { rate } \\
(\mu \mathrm{mol} \\
\left.\mathrm{CO}_{2} \cdot \mathrm{m}^{-2} \cdot \mathrm{s}^{-1}\right)\end{array}$ & $\begin{array}{c}\text { Stomatal } \\
\text { conductance } \\
(\mathrm{mol} \\
\left.\mathrm{H}_{2} \mathrm{O} \cdot \mathrm{m}^{-2} \cdot \mathrm{s}^{-1}\right)\end{array}$ & $\begin{array}{c}\text { Intercellular } \mathrm{CO}_{2} \\
\text { concentration } \\
\left(\mu \mathrm{mol} \mathrm{CO}_{2} \cdot \mathrm{mol}^{-1}\right)\end{array}$ & $\begin{array}{c}\text { Transpiration rate } \\
(\mathrm{mmol} \\
\left.\mathrm{H} 2 \mathrm{O}^{-2} \cdot \mathrm{m}^{-1}\right)\end{array}$ & $\begin{array}{c}\text { Instantaneous } \\
\text { water use } \\
\text { efficiency } \\
\left(\mathrm{mmol} \cdot \mathrm{mol}^{-1}\right)\end{array}$ \\
\hline $\mathrm{CK}$ & $14.38 \pm 0.01 \mathrm{aA}$ & $0.154 \pm 0.000 \mathrm{aA}$ & $215.89 \pm 1.22 \mathrm{cC}$ & $3.30 \pm 0.00 \mathrm{aA}$ & $4.35 \pm 0.00 \mathrm{bB}$ \\
\hline $\mathrm{LD}$ & $10.57 \pm 0.00 \mathrm{bB}$ & $0.127 \pm 0.000 \mathrm{bB}$ & $236.74 \pm 0.01 \mathrm{aA}$ & $2.80 \pm 0.00 \mathrm{bB}$ & $3.77 \pm 0.00 \mathrm{dC}$ \\
\hline $\mathrm{MD}$ & $7.72 \pm 0.00 \mathrm{cC}$ & $0.062 \pm 0.000 \mathrm{cC}$ & $179.17 \pm 0.10 \mathrm{dD}$ & $1.49 \pm 0.01 \mathrm{cC}$ & $5.16 \pm 0.02 \mathrm{aA}$ \\
\hline $\mathrm{SD}$ & $4.33 \pm 0.00 \mathrm{dD}$ & $0.045 \pm 0.001 \mathrm{dD}$ & $228.75 \pm 0.39 \mathrm{bB}$ & $1.14 \pm 0.00 \mathrm{dD}$ & $3.80 \pm 0.00 \mathrm{cC}$ \\
\hline
\end{tabular}

Different lowercase letters indicate significant differences based on one-way analysis of variance in SPSS 20.0 followed by the least significant difference test $(p<0.05) . \mathrm{CK}=$ control, $\mathrm{LD}=$ mild drought, $\mathrm{MD}=$ moderate drought, $\mathrm{SD}=$ severe drought).

\section{Acknowledgements}

This work was financially supported by the the Study on the selection and preparation of new sweet cherry varieties of Sichuan Province "13th Five-Year" breeding project (2016NYZ0034).

\section{References}

[1] M.M. Chaves, J.S. Pereira, J. Maroco, M.L. Rodrigues and C.P.P. Ricardo: Annals of Botany Vol. 89 (2002), p. 907.

[2] P.E. Verslues, M. Agarwal, S. Katiyar-Agarwal, J.H. Zhu and J.K. Zhu: The Plant Journal Vol. 45 (2006), p. 523.

[3] C.G. Grigoras, E. Destandau, S. Zubrzycki and C. Elfakir: Separation and Purification Technology Vol. 100 (2012), p. 51. 
[4] X.J. Shao, H.Q. Yang, H.T. Qiao, L. Zhang and S.Z. You: Chinese Journal of Applied Ecology Vol. 20 (2009), p. 1390.

[5] C. Liang, G. Zheng, W. Li, Y. Wang, B. Hu, H. Wang, H. Wu, Y. Qian, X. Zhu, D. Tan, S. Chen and C. Chu: Journal of Pineal Research Vol. 46 (2008), p. 40.

[6] H. Nie, Y.L. An and S.P. Li: Heilongjiang Agricultural Sciences Vol. 9 (2010), p. 88.

[7] N. Liu, Z. Jin, S. Wang, B. Gong, D. Wen, X. Wang, M. Wei and Q. Shi: Scientia Horticulturae Vol. 181 (2015), p. 18.

[8] W.X. He and Y. Zhao: Soil and Environment Vol. 9 (2000), p. 139. 